\title{
UK waives nuclear waste rule for Georgia
}

[MUNICH] Britain has temporarily waived an agreement that reprocessed nuclear fuel must be returned to its country of origin to enable it to accept a consignment of fresh and spent fuel from Georgia.

The 5.1-kg consignment, from a shutdown research reactor near Tbilisi, was transferred to a reprocessing facility at Dounreay in northern Scotland last week. The move, which has been harshly criticized by some anti-nuclear activists, was designed to reduce the risk of illegal trade in weapons-grade uranium.

Critics are angry that the agreement to import the fuel, reached between British Prime Minister Tony Blair and US President Bill Clinton, was not debated publicly, and did not take into account recent concerns about safety at the Dounreay reprocessing plants, which are at present standing idle.

Only hours before the government's announcement, the Nuclear Installations Inspectorate (NII), part of the UK government's Health and Safety Executive, had announced a ban on the import of radioactive material for reprocessing until a complete safety audit and an assessment of the plant's waste-management capability had been carried out.

In recent years, fragments of highly enriched uranium have been found on beaches near the facility, and at least one serious leak - in the dissolver tank of its fast reprocessing plant - occurred in 1996. Bringing the Dounreay plants to a safety level acceptable to the NII could take two years.

Most of the Georgian consignment is fresh fuel, which the UK Foreign Office says will be used up as raw material in Dounreay's facilities for producing medical isotopes. Only 0.8 $\mathrm{kg}$ is spent fuel requiring reprocessing; this will be stored on site until Dounreay gets the green light to recommence reprocessing.

Since the collapse of the Soviet Union, the nuclear powers have been sharing the responsibility for nuclear safety. The United States, for example, has taken $600 \mathrm{~kg}$ of highly enriched uranium (HEU) out of Kazakhstan, while Canada, Germany and France have helped tighten up safety at nuclear reactors.

"There is certainly a feeling that Britain should share some of the burden," says a UK government spokesman, arguing that there has been a "considerable overreaction to

\section{German reactor project faces safety challenge}

[MUNICH] A US nuclear watchdog organization has called for the construction of a research reactor at a German university to be suspended on the grounds that the reactor's proposed fuel has been inadequately tested for safety.

The Technical University of Munich had planned to test a sample rod of the fuel - densely packed highly enriched uranium (HEU) from the FRMII reactor in the SILOE reactor in Grenoble, France. But the university abandoned the idea when it became clear that the amount of heat generated would exceed the limits of the reactor.

Instead, university researchers tested a fuel rod of intermediate density - 1.5 grams of uranium per cubic centimetre instead of 3.0 grams - and extrapolated the results to the high-density fuels. This extrapolation was accepted by the Technische Überwachungs Verein, the German atomic-plant inspectorate that advises licensing authorities, to approve the building of the reactor, which began in 1996.

The Washington-based Nuclear Control Institute ( $\mathrm{NCl}$ ) has long argued that the reactor should not have been designed to burn weaponsgrade HEU. Under a supplementary agreement to the Nuclear Non-Proliferation Treaty, signatories agreed to convert existing HEU-burning research reactors to lowenriched uranium (LEU), and not to build new HEU-burning reactors.

The $\mathrm{NCl}$ has written to the Bavarian environment minister, who will be responsible for licensing the operation of the reactor, saying that without complete tests "it is impossible for a licensing authority to certify the safety of a proposed reactor".

But the university insists that the safety tests were sufficient and in accordance with international standards. "We have conducted tests on those parts of the fuel plates which have the highest uranium fission density," says Gert von Hassel, spokesman for the FRMII project. Thus, he says, extrapolation to HEU fuel rods is legitimate.

The $\mathrm{NCl}$ says that the risks of catastrophic accident and nuclear terrorism could be averted if the reactor were redesigned to burn lowenriched uranium fuel. A recent study by the Argonne National Laboratory (ANL) in the United States indicated that the reactor could produce the same experimental performance if it converted. But according to von Hassel, the ANL proposal is limited to fuel consideration and says nothing about safety.

The reactor could still be forced back to the drawingboard if the opposition Social Democrat Party wins power in the September federal elections. The party wants an alternative reactor, based on the LEU, to be developed.

A. A. \& Quirin Schiermeier the decision to take in such a small amount of fuel".

The research reactor from which the fuel originates is at the Georgia Institute of Physics - near Tbilisi, Georgia's capital which stopped operations after the Chernobyl disaster in 1986.

During the Soviet era, Georgia could ship its spent fuel to the Russian nuclear complex at Chelyabinsk in the Ural mountains. But in 1991 Russia ended the arrangement because, following the collapse of the Soviet Union, Georgia's status as a foreign country meant it was no longer eligible to use the Urals site.

A spokesman for the environmental group Greenpeace International, Mike Townsley, reluctantly accepts the "superficial logic" of bringing the Georgian fuel to Britain, despite concerns about safety at Dounreay, in view of bigger nuclear proliferation issues. "Given the choice between terrorists and 'mad scientists', it is obviously better to come down on the side of 'mad scientists'," he says.

"But more importantly, the Georgia affair is a wake-up call for Britain to the general dangers of the movement of weaponsgrade nuclear material which is scattered around the world." Greenpeace International is calling for an immediate full and open debate on the issue.

Britain's own rules for reprocessing foreign radioactive waste require that reprocessed fuel be returned to the country of origin for long-term storage, to prevent Britain becoming a 'nuclear dumping ground'. But this rule was waived on a 'one-off' basis for the Georgian consignment in the interests of non-proliferation, says a spokesman for the Health and Safety Executive.

US rules for supplying HEU to research reactors require that the nuclear waste be returned to the United States for storage and reprocessing, to prevent commerce in bombgrade uranium. As a consequence, Dounreay has had difficulties finding customers for its reprocessing facilities, and had to put its main reprocessing plant on idle in 1996.

But Dounreay had hoped to start reprocessing again soon, after recently winning two large contracts to reprocess spent HEU fuel rods from research reactors. One is with ICI in England, which had originally received its HEU fuel from Russia; handling its waste will require Dounreay to obtain permission to open its new reprocessing plant designed for aluminium-clad fuel.

The other contract is with the Australian Nuclear Science and Technology Organization near Sydney (see Nature 389, 109; 1997), whose research reactor was supplied with HEU fuel by Britain in the 1960s. Both the Australian body and ICI have been informed that Dounreay cannot at present accept their fuel.

Alison Abbott 